\title{
Improving curriculum development practices in a technical vocational community college: examining effects of a professional development arrangement for middle managers
}

\author{
Nabeel M. Albashiry, Joke M. Voogt \& Jules M. Pieters
}

To cite this article: Nabeel M. Albashiry, Joke M. Voogt \& Jules M. Pieters (2015) Improving curriculum development practices in a technical vocational community college: examining effects of a professional development arrangement for middle managers, The Curriculum Journal, 26:3, 425-451, DOI: 10.1080/09585176.2015.1040041

To link to this article: http://dx.doi.org/10.1080/09585176.2015.1040041

曲 Published online: 11 May 2015.

Submit your article to this journal ¿

Џll Article views: 128

Q View related articles $₫$

View Crossmark data $\nearrow$ 


\title{
Improving curriculum development practices in a technical vocational community college: examining effects of a professional development arrangement for middle managers
}

\author{
Nabeel M. Albashiry ${ }^{\mathrm{a}}$, Joke M. Voogt ${ }^{\mathrm{b}}$ and Jules M. Pieters ${ }^{\mathrm{c}}$ \\ ${ }^{a}$ Department of Research Methodology, Measurement and Data Analysis, Faculty of \\ Behavioral, Management and Social Sciences, University of Twente, AE Enschede, \\ The Netherlands; ${ }^{b}$ Research Institute of Child Development and Education, University of \\ Amsterdam, Nieuwe Prinsengracht 130, Amsterdam, The Netherlands; ${ }^{c}$ ELAN Institute \\ for Teacher Education, University of Twente, AE Enschede, The Netherlands
}

\begin{abstract}
Learning about curriculum development is critical for middle managers of technical vocational institutions in order to assume curriculum leadership in maintaining and enhancing the quality and relevance of their educational programs. This case study reports on the design and effects of a professional development arrangement (PDA), with such a focus, for 13 middle managers of a technical vocational community college in a developing country. The findings indicate that the middle managers appreciated the relevance of the PDA for curriculum development at the community college and gained substantial learning about systematic curriculum development. However, the middle managers' post-PDA curriculum development improvement efforts were minimal and characterised by individual initiatives, due to a lack of senior management support, unfavourable work conditions, and a high rate of middle manager attrition. The conclusion drawn is that for trained middle managers to lead systematic curriculum development practices, contextual and organisational barriers germane to technical vocational education in developing contexts need to be considered.
\end{abstract}

Keywords: middle management; curriculum leadership; curriculum development; professional development; TVET; developing countries

\section{Introduction}

Developing countries are becoming increasingly aware of the role that Technical Vocational Education and Training (TVET) can play in reducing poverty and supporting economic growth. Governments in these countries believe that TVET will feed the job market with qualified professionals and entrepreneurs who can make a living independently

\footnotetext{
*Corresponding author. Email: n.albashiry@utwente.nl
} 
(Bureau of the Conference of Ministers of Education of the African Union, 2007; Killian, Tendayi, \& Augustine, 2009). However, there are various implementation barriers that keep these aspirations from being realised. Challenges such as political instability, poor infrastructure for TVET institutions, huge numbers of students, and inadequate collaboration between TVET institutions and industry result in TVET curricula of low quality and relevance to the needs of stakeholders (Agrawal, 2012; Baqadir, Patrick, \& Burns, 2011; Bakah, Voogt, \& Pieters, 2012; Gervedink Nijhuis, Voogt, \& Pieters, 2012; Lai \& Lo, 2008).

In the light of this TVET landscape in developing countries, TVET institutions need to ensure systematic curriculum development practices, given the means available and the challenges encountered, such that TVET programmes are consistent with the needs of the labour market (Boateng, 2012). It is usually the academic managers at the middle level of these institutions (e.g. academic departments) who are expected to play a critical role in maintaining and enhancing the quality and relevance of TVET programmes (Albashiry, Voogt, \& Pieters, 2015; Boateng, 2012; Mazani, 2013). In practice, however, pre- and in-service professional development opportunities for TVET programme managers are reported to be scarce; as a consequence, Heads of Department (HoDs) in tertiary TVET institutions have been found to lack adequate competency in leading effective curriculum development practices, resulting in academic departments that do not have goals, and curricula that have not been reviewed for many years (Albashiry et al., 2015; Bakah et al., 2012; Gervedink Nijhuis et al., 2012; Mazani, 2013).

The effectiveness of professional development programmes on curriculum development that are designed for TVET college middle managers is an area awaiting further empirical research, especially within the context of developing countries. Therefore, the purpose of this study is to explore the perceptions of the middle managers of TVET community colleges in a developing country about the relevance of such programmes and to examine their effects on the middle managers' learning about curriculum development and on their post-training curriculum leadership practices.

\section{Study context}

Yemen, the broad context of this study, shares the TVET scene described above. Despite the turbulent political instability in the last two decades coupled with economic hardships, government attention to TVET is evident. TVET in Yemen had been handled by an administrative body attached to the Ministry of Education, but in 2001 it was assigned an independent ministry. Community colleges were introduced in 2000 as a new form of post-secondary education, and have recently been attached to the Ministry of TVET to emphasise their technical and vocational 
orientation. These colleges offer three-year specialised degree programmes with the mission of developing a middle-level skilled workforce, to address the need for a stronger link between post-secondary education and employment in the corporate and industrial sector (Shumaker, 2013). The Ministry of TVET does not yet have accreditation standards for community colleges to abide by, nor do these colleges have active curriculum development units to provide guidance on programme/course renewal, thus leaving academic departments to struggle with establishing, maintaining, and updating their academic programmes.

Liberty Community College (LCC), a pseudonym, the specific context of this study, is a leading public TVET institution that has now 10 diploma departments, with each one being managed by an HoD. Departments are grouped into divisions by academic discipline, and each division is chaired by a Head of Division (HoDiv) who is expected to coordinate the academic processes of the affiliated departments. Early academic programmes were developed through a foreign project (a group of experts from USA Community Colleges) and the later ones by subject-matter experts most of whom no longer work at LCC. The minimum academic degree required for teachers to work at community colleges is a four-year bachelor's degree in a discipline related to the department where they will teach, but they often have not received pre-service formal training on pedagogy or curriculum development.

A previous exploratory study (Albashiry et al., 2015) identified several college-wide sub-standard curriculum development practices jeopardising the college programmes' external consistency (i.e. relevance of the programmes to the external stakeholders' expectations) and internal consistency (i.e. harmony between elements such as needs analysis, learning goals, instructional strategies, and evaluation). Two major curriculum development practices stood out. First, there was a major problem with the departments' formal curricula (i.e. programme specifications, course descriptions, and curriculum policies), as these curricular documents were missing or ill-defined. Second, curriculum development practices were found to be mostly individual, intuitive, and ad hoc. They also tended to be limited to individual courses, thereby failing to achieve interconnectedness of the whole academic programme. Such practices were attributed, in part, to the inadequate expertise of the HoDs and HoDivs for assuming effective curriculum leadership.

\section{Conceptual framework}

\section{Curriculum development and curriculum leadership}

Curriculum development, defined as 'the process of planning, constructing, implementing and evaluating learning opportunities intended to 
produce desired changes in learners' (Print, 1993, p. 23), is essential for realising high quality and relevant curriculum (Diamond, 2008). While there are several approaches to curriculum development (Marsh \& Willis, 1999; Visscher-Voerman, Gustafson, \& Plomp, 1999), curriculum development at the programme level is commonly conducted through a systematic approach (Gustafson \& Branch, 2002). A key activity in this systematic approach is the development of the curriculum (programme) learning outcomes, which then form the basis for subsequent development activities such as selecting the programme content, learning strategies, and assessment methods (Visscher-Voerman et al., 1999). This approach is often conceptualised as involving an iterative cycle of five phases: analysis, design, development, implementation, and evaluation (Piskurich, 2006). However, simply applying this approach does not in itself yield optimal results according to Kessels (1999). Kessels explains that a relational approach that involves stakeholders in the curriculum development process is also needed to ensure the responsiveness of the curriculum to the needs of concerned stakeholders. This relational approach is centred on extensive collaboration and deliberations between the curriculum developers and the stakeholders throughout the development process in order to reach consensus about the main features of the educational programme, such as its outcomes, content, pedagogy, and assessment (Kessels \& Plomp, 1999).

Adopting a systematic and relational approach holds great potential for the development of the TVET curriculum, given its unique features. The TVET curriculum focuses on the provision of hands-on learning experiences for students, equips them with a broad array of skills such as job search and entrepreneurial skills needed to succeed in the world of work, and requires constant updating to be responsive to the changing needs of the community and labour market (Agrawal, 2012; Boateng, 2012; Finch \& Crunkilton, 1999). The unique nature of the TVET curricula and the challenges TVET institutions encounter demand competent managers who will assume purposeful curriculum leadership (Boateng, 2012; Bureau of the Conference of Ministers of Education of the African Union, 2007; The European Centre for the Development of Vocational Training, 2011).

A growing body of analytical and empirical research indicates that academic managers are increasingly expected to perform curriculum leadership tasks: defining and sharing the curriculum purpose (i.e. mission, goals, and standards), promoting external and internal collaboration with curriculum stakeholders, providing a structure for curriculum development work, and coordinating the various and complex curriculum development activities (Nguyen, 2012; Wiles, 2009). 'Curriculum leaders' focus on two main functions: maintaining the curriculum and advancing it to a better state (Wiles, 2009). The first involves conducting regular reviews, thereby ensuring compliance with accreditation standards and the 
availability of necessary resources, while the latter requires updating the academic programmes/courses, setting new goals, and initiating innovations for better student learning.

Academic managers, as curriculum leaders, are expected to monitor the fulfilment of programme/course plans by coordinating efforts throughout three major curriculum development phases (Lattuca \& Stark, 2009). First, during the development phase, they ensure that the learning outcomes of the programmes and courses are articulated and upto-date. Second, during the implementation phase, they ensure the availability of staff and materials and facilitate other relevant processes such as communicating with teachers and students and motivating teachers. Finally, during the evaluation phase, they monitor student progress, assess the implementation of the intended plans, and adjust them accordingly.

Review of the literature addressing curriculum leadership (Glatthorn, Boschee, Whitehead, \& Boschee, 2012; Marlow \& Minehira, 1996; Sorenson, Goldsmith, Mendez, \& Maxwell, 2011; Stark, Griggs, \& RowlandPoplawski, 2002) reveals diverse and sometimes divergent views about roles, tasks, and activities (terms used inconsistently) associated with curriculum leadership. A synthesis of this literature suggests three overlapping curriculum leadership domains within which 'curriculum leaders' function. The three domains are as follows: 1 - the curriculum development domain, concerning the technical curriculum development tasks and activities that academic managers need to work on with others; 2 - the administrative domain, referring to the routine administrative tasks that keep the educational process running; and 3 - the leadership domain, concerning leadership roles and practices expected of academic managers if they are to perform effectively in the other two domains. Of these three domains, the curriculum development domain is the one least attended to by college middle management for several reasons, one of which is the lack of professional support (Albashiry et al., 2015; Nguyen, 2012; Stark et al., 2002; Wolverton, Ackerman, \& Holt, 2005). The current study reports on the design and effects of a professional development arrangement (PDA) that focused on improving middle managers' learning about curriculum development, so that they could better lead the curriculum development tasks associated with the curriculum development domain.

\section{Professional development on curriculum development}

For academic managers to practice effective curriculum leadership, learning about curriculum development is critical (Marlow \& Minehira, 1996; Mazani, 2013). Professional development programmes designed for academic managers should address essential understanding of curriculum development principles, concepts, and processes (Glatthorn et al., 2012; 
Print, 1993). Besides addressing these content aspects, four major design aspects need to be considered when designing professional development programmes for academic managers (Aziz et al., 2005; Chiriboga, 2003; Darling-Hammond, Meyerson, LaPointe, \& Orr, 2009; Wilson \& Xue, 2013; Wolverton et al., 2005).

First, the content and design aspects of these programmes need to be contextually driven by the desired knowledge and skills to be developed by the academic managers rather than solely by the lists of tasks found in literature. The design also needs to attend to the organisational culture and structure. Second, the senior managers need to be involved in the design of the professional development programme from the very beginning. They should be aware of or take part in determining the goals, content, and structure of these programmes, as such involvement adds credibility to the programme from the middle managers' perspective. Third, the programme should extend over a period of time rather than taking the form of one-shot training, so that adequate time is provided for participants' discussions and reflections. Fourth, the programme should not be confined only to knowledge delivery through formal workshops but should adopt multiple delivery strategies such as training sessions, coaching, hands-on activities, site visits, and the provision of handouts and exemplary materials.

\section{Research questions}

Kirkpatrick's model (Kirkpatrick \& Kirkpatrick, 2006) suggests four levels for evaluating and understanding the effects of professional development programmes: 1 - reaction, 2 - learning, 3 - behaviour, and $4-$ results. First, participants' reactions towards the professional development experience need to be captured, as negative reactions demotivate the participants and reduce the possibility of their learning. Second, the resultant learning, defined as 'the extent to which participants change attitudes, improve knowledge, and/or increase skill as a result of attending the program' (p. 22), needs to be examined based on the pre-set goals of the programme. Third, participants' behaviour, i.e., new on-the-job practices resulting from the training, needs to be evaluated. The fourth level (results) refers to the ultimate outcomes for the sake of which the training programme was initially developed, for instance, increased production, decreased costs, and reduced turnover.

Literature on the design and effects of professional development programmes for TVET college middle management, with a focus on curriculum development, is currently limited (cf. Darling-Hammond et al., 2009). Thus, this study will address the overall question: What are the effects of a PDA on curriculum development practices for college middle managers in a TVET community college? Addressing the first three levels 
of Kirkpatrick's model (due to the scope of the study), the study's overall question is operationalised into the following three sub-questions:

(1) Reaction: How do the middle managers perceive the relevance of the PDA to their work?

(2) Learning: What are the effects of the PDA on the middle managers' learning about curriculum development?

(3) Behaviour: What are the effects of the PDA on the middle managers' curriculum development practices?

\section{Methods}

Because this study aimed to provide an in-depth description and explanation of the impact of an intervention in its contemporary real-life setting, a case study approach (Yin, 2003) was used. The case was the PDA, the context was LCC, and the units of analysis were the middle managers. In line with Yin's reasoning, the study endeavoured to contribute to the theoretical understanding, analytical generalisation, of how such an intervention played out for a specific group of people in a specific context. Another reason for using a case study approach is the flexibility it affords in using multiple methods of data collection and, hence, multiple ways of building up evidence (Schell, 1992), as demonstrated by our use of both quantitative and qualitative data analysis. Furthermore, Borko (2004) explains that research addressing educators' professional development should first be conducted on a single professional development programme at a single site, focusing on 'the professional development program, teachers as learners, and the relationships between these two elements of the system' (p. 4).

\section{Participants}

Thirteen out of 16 middle managers, HoDs (10) and HoDivs (3), participated in this study on a voluntary basis. Only four out of the thirteen managers had previous training on some curriculum development aspects, such as lesson planning and formulation of learning goals. Table 1 shows other background information about the study participants. It can be observed from the table that the majority of the middle managers had a four-year bachelor degree and had served in their current positions for less than a year.

\section{Intervention: professional development arrangement}

A PDA was coordinated by the first author (the project coordinator). Based on the findings of the previous exploratory study (Albashiry et al., 


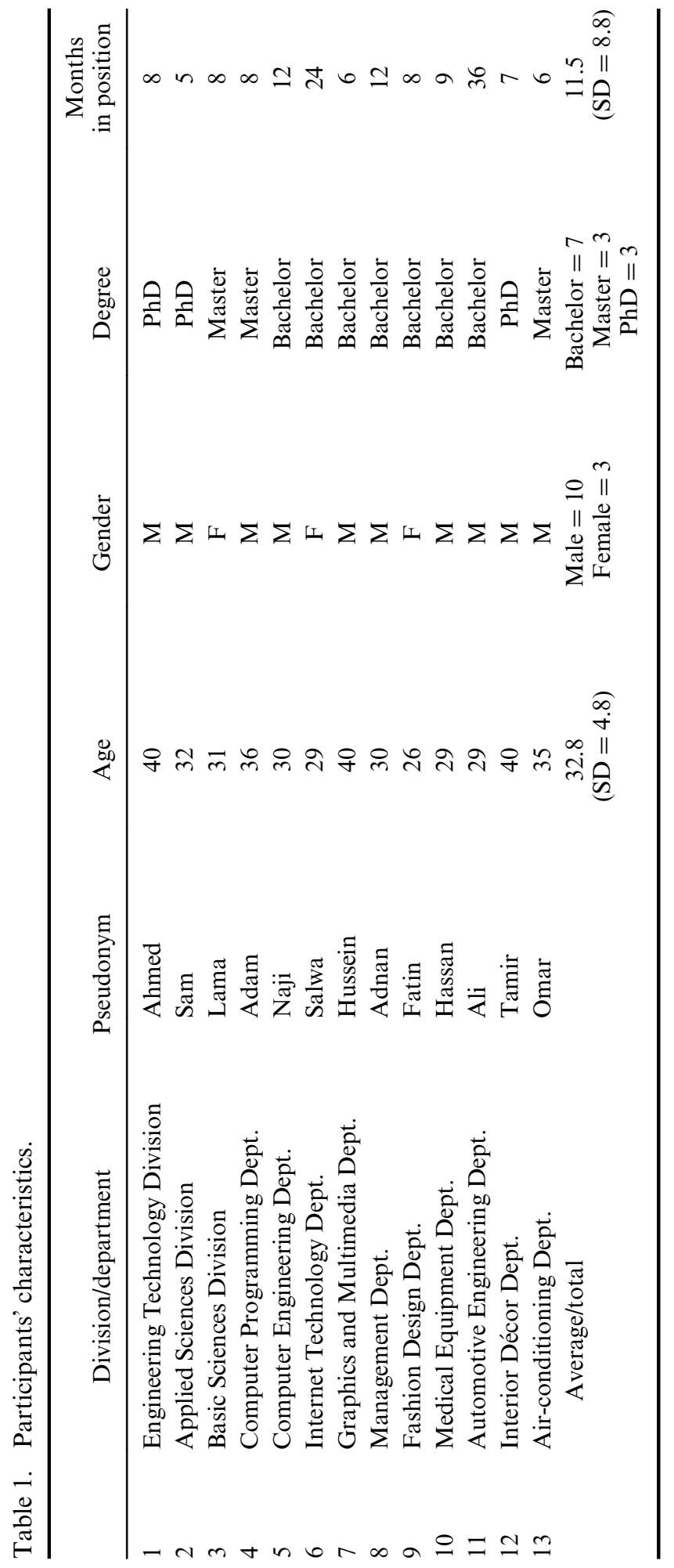


2015), three broad goals were set for the PDA and shared by the middle managers, the senior management, and the project coordinator. These goals indicated that based on their participation in the PDA, the participating middle managers would be expected to: 1 - develop basic learning about curriculum development, 2 - develop college-wide curriculum development policies, and afterward 3 - improve the current curriculum development practices in their departments. The first goal was operationalised into five learning goals, that is, learning about: 1 - systematic and relational curriculum development, 2 - curriculum stakeholders and the importance of their involvement, 3 - programme/course description, 4 programme/course evaluation, and 5 - curriculum policy development. The participants' learning was later evaluated by a knowledge test which was informed by these five learning goals (see the Data collection and analysis section).

For the second PDA goal, the participants, with help from the project coordinator, collaboratively developed four curriculum policies to regulate programme and course planning and evaluation activities such as The Program Annual Review Policy. Each policy comprised the policy goal, definitions, description, administrative procedures, people in charge, templates, and forms. For the third PDA goal, the middle managers were expected to apply what they had learned and implement the policies developed such that they could improve the two major sub-standard curriculum development practices identified in the exploratory study (the poor writing of the formal curriculum and the arbitrary programme/course development practices).

Besides being context-driven, both the content and the design of the PDA were informed by the conceptual framework of the study. The content of the PDA addressed basic curriculum development concepts such as the broad definition of 'curriculum', curriculum components, curriculum stakeholders, and types of programme learning outcomes. The PDA content also addressed how educational programmes and courses are developed and evaluated systematically and relationally, and how they are clearly and thoroughly described. In the PDA design, the four design principles discussed in the conceptual framework were considered as follows.

\section{Principle 1: attending to managers' learning needs and contextual factors}

The PDA was developed based on the managers' expressed need for learning about systematic curriculum development. The PDA also responded to the managers' need to have clear procedures to follow when planning or evaluating the programmes and courses (i.e. policy development). Other contextual considerations included the provision of extrinsic motivation for the participating managers (e.g. monetary incentives and 
training certificates), and the scheduling of the training sessions at different time slots during the day to reduce potential conflicts with the participants' teaching schedules.

\section{Principle 2: senior management involvement}

The Dean and his vice-Dean for academic affairs (both recently appointed) were invited to the orientation, opening, and closing workshops. The purpose was to give them an idea about the project, inform them about the findings of the exploratory study, and establish their ownership and commitment. They were also regularly briefed on the progress of the project.

\section{Principle 3: time span}

The PDA extended over an academic semester to allow for participants' reflections and collegial discussions over the topics introduced and to accommodate the several activities of the PDA: the orientation workshop, the opening workshop, the training sessions, the policy development, and the redesign of courses. Table 2 provides an overview of the chronological structure of the PDA, including the activities that were organised, the purposes of these activities, and the relevant design principles. The development of the intervention occurred in the gap between month 1 and month 3 .

\section{Principle 4: adoption of multiple delivery strategies}

In conformity with this principle, four main strategies were adopted during the PDA: 1 - the trainer's instruction (explanation of concepts), 2 the use of exemplary materials, hand-outs, and templates, 3 - the use of practical tasks (i.e. the policy development and course redesign), and $4-$ the extended time span of the PDA that allowed for participants' reflection and collaboration.

\section{Data collection and analysis}

Four data collection methods (questionnaires, interviews, curriculum documents, and field notes) were used to allow for triangulation of findings (Yin, 2003). Besides triangulation, sound procedures in cleaning up, analysing, and interpreting the data were followed to improve the reliability of the study (Shenton, 2004). The development of instruments was informed by the conceptual framework and by the research questions. An overview is presented in Table 3. Reliability coefficients (Cohen's kappa and Cronbach's alpha) were also calculated after administering the questionnaires and coding the interviews. 
Table 2. PDA main activities, purposes, and relevant design principles.

\begin{tabular}{|c|c|c|c|}
\hline Time/duration & Activity and participants & Purpose & $\begin{array}{c}\text { Design } \\
\text { principle }\end{array}$ \\
\hline $\begin{array}{l}\text { Month } 1 \text { (two- } \\
\text { hour session) }\end{array}$ & $\begin{array}{l}\text { Orientation workshop } \\
\text { attended by the vice-Dean } \\
\text { and some HoDs and } \\
\text { HoDivs }\end{array}$ & $\begin{array}{l}\text { Sharing the findings of the } \\
\text { exploratory study and } \\
\text { agreeing on the } \\
\text { intervention (the PDA) } \\
\text { and its overall goal }\end{array}$ & $\begin{array}{l}\text { Principles } 1 \\
\text { and } 2\end{array}$ \\
\hline $\begin{array}{l}\text { Month } 3 \text { (two- } \\
\text { hour session) }\end{array}$ & $\begin{array}{l}\text { Opening workshop attended } \\
\text { by the Dean, vice-Dean, } \\
\text { and most of the HoDs and } \\
\text { HoDivs }\end{array}$ & $\begin{array}{l}\text { Agreeing on the specific } \\
\text { outcomes of the PDA and } \\
\text { an action plan }\end{array}$ & $\begin{array}{l}\text { Principles } 1 \\
\text { and } 2\end{array}$ \\
\hline $\begin{array}{l}\text { Months 3-4 } \\
\quad \text { (three weeks) }\end{array}$ & $\begin{array}{l}\text { Training sessions for middle } \\
\text { managers: five sessions } \\
\text { spread over three weeks, } \\
\text { each one lasting two hours. } \\
\text { Sessions included } \\
\text { discussions and learning } \\
\text { activities. }\end{array}$ & $\begin{array}{l}\text { Introducing basic concepts } \\
\text { about systematic and } \\
\text { relational curriculum } \\
\text { development and the } \\
\text { writing of the formal } \\
\text { curriculum }\end{array}$ & $\begin{array}{l}\text { Principles } 1 \\
\text { and } 4\end{array}$ \\
\hline $\begin{array}{l}\text { Month } 4 \text { (three } \\
\text { weeks) }\end{array}$ & $\begin{array}{l}\text { Collaborative curriculum } \\
\text { policy development by } \\
\text { middle managers followed } \\
\text { by two plenary workshops } \\
\text { for refinement }\end{array}$ & $\begin{array}{l}\text { Having college-wide policies } \\
\text { that standardise the } \\
\text { current arbitrary } \\
\text { curriculum development } \\
\text { practices }\end{array}$ & $\begin{array}{l}\text { Principles } 1 \\
\text { and } 4\end{array}$ \\
\hline $\begin{array}{l}\text { Month } 5 \text { (two } \\
\text { weeks) }\end{array}$ & $\begin{array}{l}\text { Course re-design: participants } \\
\text { worked in groups on re- } \\
\text { designing and re-describing } \\
\text { some actual courses }\end{array}$ & $\begin{array}{l}\text { Improving the participants' } \\
\text { design skills }\end{array}$ & $\begin{array}{l}\text { Principles } 1 \\
\text { and } 4\end{array}$ \\
\hline $\begin{array}{l}\text { Month } 5 \text { (two- } \\
\text { hour session) }\end{array}$ & $\begin{array}{l}\text { Closing workshop attended by } \\
\text { the Dean and all } \\
\text { participants }\end{array}$ & $\begin{array}{l}\text { Discussing the next step for } \\
\text { the middle managers after } \\
\text { the training and policy } \\
\text { development }\end{array}$ & Principle 2 \\
\hline
\end{tabular}

Table 3. Data collection methods per research question.

\begin{tabular}{|c|c|c|c|c|c|c|c|}
\hline Research question & $\begin{array}{l}\text { Ques.* }^{*} \\
\text { (1) }\end{array}$ & $\begin{array}{l}\text { Ques. } \\
(2)\end{array}$ & $\begin{array}{l}\text { Pre- } \\
\text { int.* }\end{array}$ & $\begin{array}{l}\text { Post-int. } \\
\text { (1) }\end{array}$ & $\begin{array}{l}\text { Post-int. } \\
\text { (2) }\end{array}$ & $\begin{array}{l}\text { Curriculum } \\
\text { docs }\end{array}$ & $\begin{array}{l}\text { Field } \\
\text { notes }\end{array}$ \\
\hline $\begin{array}{l}1 \text { - How do the middle } \\
\text { managers perceive the } \\
\text { relevance of the PDA to } \\
\text { their work? }\end{array}$ & $X$ & & & $\mathrm{X}$ & $\mathrm{X}$ & & \\
\hline $\begin{array}{l}2 \text { - What are the effects of the } \\
\text { PDA on the middle } \\
\text { managers' learning about } \\
\text { curriculum development? }\end{array}$ & $X$ & $X$ & $X$ & $X$ & $X$ & $\mathrm{X}$ & $X$ \\
\hline $\begin{array}{l}3 \text { - What are the effects of the } \\
\text { PDA on the middle } \\
\text { managers' curriculum } \\
\text { development practices? }\end{array}$ & & & & & $X$ & $\mathrm{X}$ & $\mathrm{X}$ \\
\hline
\end{tabular}

Note. ${ }^{*}$ Ques. = questionnaire; int. = interview. 


\section{Questionnaires}

Two questionnaires were administered to the 13 study participants. The first one was a reaction questionnaire adapted from Piskurich (2006). It intended to capture the participants' reactions to the PDA design and content, and the participants completed it at the end of the closing workshop. Along with open-ended questions, this questionnaire included a five-point Likert-type scale $(1=$ very poor to $5=$ very good; 9 items, $\alpha=$ .79). Examples of scale items included the participants' perceptions about the quality of the learning materials provided during the PDA (e.g. handouts, exemplary materials, and templates), the relevance of the training to the participants' job as middle managers, and the practical activities they participated in during the PDA. The second questionnaire $(10$-point rating scale, $1=$ the lowest to $10=$ the highest , 15 items, $\alpha=$ .95) was developed to measure the participants' perceptions of their knowledge of curriculum development concepts and processes, assessed before and after the intervention. Examples of questionnaire items are as follows: 'I know how the programme learning outcomes are developed/updated'; 'I know how to align the TVET programme with the needs of the labor market'; and 'I know how to evaluate the TVET program'. The Wilcoxon signed-rank test (due to the small sample size) was used to find out whether the pre- and post-scores for knowledge differed significantly.

\section{Interviews}

Three semi-structured interview guides were developed and then conducted with the study participants at three successive time points. The first one, pre-intervention, was conducted before the PDA started. It explored themes such as the participants' current curriculum development practices and their willingness to participate in a professional and curriculum development project. The second one, post-intervention (1), was administered during the first two weeks after the closing workshop. It aimed at identifying any change in the participants' beliefs and learning about curriculum development. Moreover, the interview examined the participants' reactions to and perceptions about the PDA and its relevance to their job as middle managers. The third interview, post-intervention (2), was conducted with the HoDs, who were still in such a position $(N=4)$, an academic semester later to see how much they had managed to improve the curriculum development practices in their departments, and to explore what challenges they encountered.

All interviews were audiotaped and segments related to the study research questions were transcribed. The general inductive approach (Thomas, 2006) was used as a framework for analysing the qualitative data from the interviews. This approach is similar to Miles and 
Table 4. Results of the coding process.

\begin{tabular}{|c|c|c|c|c|c|}
\hline Research goals & Data source & $\begin{array}{l}\text { Number } \\
\text { of codes }\end{array}$ & $\begin{array}{c}\text { Cohen's } \\
\text { kappa }\end{array}$ & $\begin{array}{l}\text { Example } \\
\text { code }\end{array}$ & Example quotation \\
\hline $\begin{array}{l}\text { Current } \\
\text { curriculum } \\
\text { development } \\
\text { practices }\end{array}$ & $\begin{array}{l}\text { Pre-intervention } \\
\text { interview }\end{array}$ & 10 & .86 & $\begin{array}{l}\text { Content-centred } \\
\text { course } \\
\text { planning }\end{array}$ & $\begin{array}{l}\text { 'I was assigned a course with } \\
\text { incomplete content. I had to } \\
\text { search for content. . So I } \\
\text { developed the course } \\
\text { choosing important content } \\
\text { from websites of colleges } \\
\text { offering the same course' }\end{array}$ \\
\hline $\begin{array}{c}\text { Post-intervention } \\
\text { learning gains }\end{array}$ & $\begin{array}{l}\text { Post-intervention } \\
\text { interview 1-- } \\
\text { Questionnaire } \\
\text { (1) }\end{array}$ & 8 & .82 & $\begin{array}{l}\text { Systematic } \\
\text { planning }\end{array}$ & $\begin{array}{l}\text { 'I learned about the steps of } \\
\text { analysis, design, evaluation } \\
\text { and the procedures that need } \\
\text { to be followed in developing } \\
\text { our programs and courses' }\end{array}$ \\
\hline $\begin{array}{l}\text { Implementation } \\
\text { challenges }\end{array}$ & $\begin{array}{c}\text { Post-intervention } \\
\text { interview (2) }\end{array}$ & 3 & .77 & $\begin{array}{l}\text { Inadequate top } \\
\text { management } \\
\text { support }\end{array}$ & $\begin{array}{l}\text { 'The top management was } \\
\text { encouraging but verbally, } \\
\text { without taking action' }\end{array}$ \\
\hline
\end{tabular}

Huberman's (1994) analytic framework of data reduction, data display, and conclusion drawing, except that it provides more specific procedures for analysing, reporting, and linking data to the research goals. The interview data were cleaned, put into a common format, and then transferred to qualitative data analysis software (Atlas.ti7). Guided by the research goals, codes (themes) were identified and refined through several readings and interpretations. To ensure an acceptable level of consistency of interpretation of these major themes, Cohen's kappas were calculated (with the help of colleagues, functioning as second coders) on a random sample of representative quotations. Table 4 illustrates the results of the coding process.

Moreover, a number of strategies for generating meaning (Miles \& Huberman, 1994) were used, such as counting occurrences, observing emergent themes, grouping, and building a logical chain of evidence.

\section{Curriculum documents and field notes}

Two types of documents were used for analysis: 1 - the meeting minutes of the participants who worked on redesigning actual courses - to capture their design process, and 2 - the old and new course descriptions for the redesigned courses - to see the level of clarity and detail of these course descriptions. Field notes were also taken throughout the project. The analysis of the meeting minutes and the field notes was informed by Miles and Huberman's (1994) analytical framework of generating meaning as explained above, and the course descriptions were analysed using a checklist based on the ten components of curriculum (Van den Akker, 2003). 


\section{Findings}

\section{How do the middle managers perceive the relevance of the PDA to their work?}

At the reaction level of Kirkpatrick's model, the data mainly from the reaction questionnaire and from post-intervention interview (1) showed that all middle managers found the various PDA topics and activities relevant to and supportive of their curriculum work. Regarding the PDA content, the participants highly valued the topics the PDA addressed and explained that their conceptual knowledge about such topics would help them do better work in leading or participating in curriculum development committees. The participants also noted the importance of the curriculum policy development part of the PDA. Ahmed explained that the policies developed during the project, such as the Course Evaluation Policy, would now be the reference point guiding their curriculum work as middle managers. The following quotations from post-intervention interview (1) captured the participants' reactions.

Lama: The project [the PDA] is $100 \%$ related to my work. My work as a teacher and as Head of Division who deals with students, teachers, and HoDs requires that I know how to develop, assess, and evaluate the curriculum, what to focus on, what weaknesses to work on.

Fatin: Now I feel that I am able to develop a curriculum for certain courses or participate in a curriculum development committee. I feel very confident, but before I lacked this confidence greatly because you did not know what to do and on what basis you would go on.

Hussein: The ideas introduced during the training sessions were very useful to my work... It's important that the HoD has clear policies regarding issues such as hiring teachers and changing a course. The HoD can avoid lots of trouble when using such policies.

The descriptive statistics for the reaction questionnaire (Table 5) and the qualitative data analysis also captured the participants' positive reaction to the four delivery strategies employed in the PDA (i.e. principle 4). The use of exemplary materials and templates was highly valued by the

Table 5. Participants' reaction to PDA delivery strategies $(N=13)$.

\begin{tabular}{|c|c|c|c|c|c|c|}
\hline & \multicolumn{3}{|c|}{ Frequency } & \multicolumn{3}{|c|}{ Central tendency } \\
\hline & Fair & Good & Very good & Median & Mode & Mean (SD) \\
\hline Exemplary materials and templates & - & 4 & 9 & 5 & 5 & $4.69(.48)$ \\
\hline Trainer's instruction & - & 4 & 9 & 5 & 5 & $4.69(.48)$ \\
\hline Practical tasks & 2 & 7 & 4 & 4 & 4 & $4.15(.68)$ \\
\hline Logistics (timing and spacing) & 3 & 3 & 7 & 5 & 5 & $4.13(.85)$ \\
\hline
\end{tabular}


participants. They pointed out that such resources and tools helped them better understand the concepts introduced during the PDA, guided them in the course re-design undertaking, and would help them in their future curriculum work. The practical tasks (i.e. development of curriculum development policies and re-design of courses) were also appreciated by the participants. These hands-on activities were useful, according to Sam, as they enhanced his understanding of the concepts introduced during the training. An emerging theme from the participants' comments concerned appreciation of the opportunities to collaborate with their colleagues. Tamir stated, 'What inspired me personally was the collaboration and active participation of the participants which made me feel that there is still a collaborative environment in the college through which we can work to achieve the goals of the training'.

Although most of the participants were satisfied with the PDA logistics (timing and spacing), about half of the managers reported conflicts between their teaching schedules and the PDA activities. This led some of them to skip their classes at times to attend the training sessions and work on the practical curriculum development tasks. Naji suggested the offering of time release by the senior management, so that participants could better focus on the project activities without interruptions.

\section{What are the effects of the PDA on the middle managers' learning about curriculum development?}

Based on defining learning as 'the extent to which participants change attitudes, improve knowledge, and/or increase skill as a result of attending the [training] program' (Kirkpatrick \& Kirkpatrick, 2006, p. 22), the PDA endeavoured to attend to these aspects in supporting the middle managers' learning about curriculum development.

The middle managers' beliefs about curriculum development either changed or were reinforced as a result of participating in the PDA. A major reported change concerned the managers' perceptions of the concept of 'curriculum'. Eight out of ten participants who addressed this topic during the post-intervention interviews, explained that the 'curriculum' was limited to the individual courses they were supposed to teach, and that curriculum development was synonymous with finding a recent book or a handout to cover during a semester. However, after the intervention they realised that the 'curriculum' has a broader meaning that includes the programme/course learning outcomes, content, instructional strategies, assessment and other aspects that need to be considered altogether, as pointed out by Fatin. Another change in beliefs pertained to the complexity of the curriculum development process. Five out of seven participants who commented on this topic had considered curriculum development an easy process that involved searching for relevant and 
updated content. However, after the intervention they believed it was quite complex requiring several people, much time, and rigorous effort. The following quotations from post-intervention interview (1) illustrate these belief changes:

Salwa: The curriculum for me was a list of topics given to the teacher to teach... and dividing these topics over a period of time. But now the curriculum is about having objectives, content, instructional strategies... and linking the course goals to the program goals. The concept of curriculum has become broader.

Hussein: Before the workshops, the word 'curriculum' was just limited to the book, but after the training we knew that it is the plan to achieve specific goals for specific students within the learning outcomes that the curriculum has specified.

On the other hand, beliefs that the managers reported were reinforced pertained to approaching curriculum development systematically and collaboratively. For example, Omar explained that:

For me, the concept of curriculum was a plan that you follow, a plan containing objectives and many other things, as we learned during the workshops, and you see in the end if you have achieved them. This concept has now been enhanced in addition to the importance of standardising these aspects.

Regarding the participants' knowledge gained about curriculum development, the various data sources provided evidence of the participants' substantial gains in knowledge about curriculum development. A Wilcoxon signed-ranks test indicated that the participants' perceptions of their knowledge about curriculum development significantly improved after the intervention $(M d n=9.13)$ compared to their pre-intervention knowledge $(M d n=6.6), Z=-3.11, p=.002$, and Cohen's $d=2.65$.

Analysis of qualitative data (from the various sources pertaining to this research question, see Table 3) revealed several themes that can be grouped into four main categories. First, the participants reported having learned about general concepts and principles of curriculum development, including the two major issues that the PDA focused on (i.e. how to develop the department curriculum systematically and relationally, and how to describe it clearly and thoroughly). The concept most frequently mentioned in relation to new learning was the broad meaning the term 'curriculum' could take (as previously discussed). The second major learning theme concerned how to approach curriculum development systematically. Within this major theme, the participants reported having learned about core issues related to a systematic curriculum development process, for example, the five generic curriculum development phases of analysis, 
design, development, implementation, and evaluation, the involvement of curriculum stakeholders, and the development of programme and course learning outcomes. Adam explained:

I believed that curriculum development had to be systematic but did not know how to do it; this belief has been enhanced and I know how to do it now.

\section{In the words of Naji:}

[The PDA was] very useful for me, for example, in evaluating the course. Is the course related and supportive for the program? Is the program itself relevant to the labor market? I learned to focus on the learning outcomes of the students when they graduate - do these outcomes exist? Are they adequate for the labor market? I also learned how to evaluate the teacher, the course, the program in general.

The third learning theme pertained to collaborative curriculum development. Although some managers initially believed in collaboration, they did not know how to go about it. The participants reported not only their learning about the importance of teacher collaboration in developing the department curriculum, but also the importance of extending collaboration to include the college senior management, experts, and the potential employers of the college graduates. Khalid stated, 'Another aspect we learned was how to work collaboratively. I believed that curriculum development was collaborative but I did not know how to go about it and what the standards were'. Salwa said, 'I prefer now that the department teachers develop the academic course collaboratively because if left to an individual, this person might stop teaching this course, which can cause problems'.

Fourth, the participants reported having learned about how important the development of college-wide curriculum policies was in order to regulate curriculum work in the departments. As Ali pointed out:

The training helped me through giving me guiding ideas for managing the curriculum development activities. As a head of department I will do things, but on what basis? The training showed me how to confidently follow systematic procedures according to certain policies so that no one can criticize me!

Besides the above self-reported knowledge acquisition, the collaborative re-designing of actual courses provided an indicator of the middle managers' improved curriculum development skills. Prior to the intervention, the participants indicated, in the pre-intervention interview, that curriculum development centred around finding relevant and recent course content from books, manuals, and websites. After the training sessions and the policy development activity, the participating managers worked 
collaboratively in four teams (based on the academic division to which they belonged) to redesign an actual course. Analysis of the meeting minutes and the new course descriptions revealed three common curriculum development practices applied by the teams, which had been previously missing. First, three out of the four teams paid special attention to the analysis phase. These teams started by assessing the current course through surveying the course teachers and students, via questionnaires and interviews, to get their feedback about what needed to be improved. The following text from the meeting minutes of team (a) captures this practice:

Team a: First, we started with the analysis process to facilitate the development phase and reduce the risks of taking wrong decisions through feeding it with real and objective data... it was necessary to get the students' and teachers' opinions about the course through discussion sessions based on pre-developed discussion points that were agreed upon by the team.

The fourth team, however, did not see the need for going through an analysis phase as they perceived their course to be fine, and that all it needed was elaboration of its description, focusing on the formulation of its learning outcomes. The second common practice was formulating the course learning outcomes and the specific performance elements for each outcome. The participants reported having ensured that the course learning outcomes and the performance elements were written in a measurable form, and that they were connected to the other elements of the course design. The following excerpt from the meeting minutes of team (b) illustrates this theme.

Team b: We started with formulating the course overall goal, the learning outcomes, and the specific performance elements in clear and specific terms. The team members did this in the discussion sessions and based on what we learned about course development...

The third improved practice demonstrated by the teams was the clarity and detail with which the new course descriptions were written. Analysis of the new course descriptions compared to their old versions showed better attention to various curriculum components in course design (Van den Akker, 2003), as illustrated in Table 6. Old course descriptions were mostly lists of topics to be covered. There was also clear improvement in the clarity and detail of these components in the new course descriptions, compared to the old ones. For example, the 'content' component in the old course descriptions was a list of topics sorted by week while in the new descriptions it has improved into a roster showing the content, learning activities, type of session, and a relevant assignment for each weekly session. 
Table 6. Presence of the ten components in the new vs. old course descriptions $(n=4)$.

\begin{tabular}{|c|c|c|c|c|c|c|c|c|c|}
\hline & \multirow[b]{2}{*}{ Course component } & \multicolumn{2}{|c|}{ Course 1} & \multicolumn{2}{|c|}{ Course 2} & \multicolumn{2}{|c|}{ Course 3} & \multicolumn{2}{|c|}{ Course 4} \\
\hline & & $\mathrm{OD}^{*}$ & $\mathrm{ND}^{*}$ & OD & ND & OD & ND & OD & ND \\
\hline 1 & Rationale & & $\mathrm{X}^{*}$ & & & & & & $\mathrm{X}$ \\
\hline 2 & Learning goals/objectives & $\mathrm{X}$ & $\mathrm{X}$ & $\mathrm{X}$ & $X$ & $X$ & $X$ & & $\mathrm{X}$ \\
\hline 3 & Content & $\mathrm{X}$ & $\mathrm{X}$ & $\mathrm{X}$ & $\mathrm{X}$ & $\mathrm{X}$ & $\mathrm{X}$ & $\mathrm{X}$ & $\mathrm{X}$ \\
\hline 4 & Learning activities & & $\mathrm{X}$ & & $\mathrm{X}$ & & $\mathrm{X}$ & & $\mathrm{X}$ \\
\hline 5 & Assessment & $\mathrm{X}$ & $\mathrm{X}$ & $\mathrm{X}$ & $\mathrm{X}$ & & $X$ & $\mathrm{X}$ & $\mathrm{X}$ \\
\hline 6 & Learning resources & $\mathrm{X}$ & & $\mathrm{X}$ & $\mathrm{X}$ & $\mathrm{X}$ & $\mathrm{X}$ & & $\mathrm{X}$ \\
\hline 7 & Teacher role & & $X$ & & $\mathrm{X}$ & & $\mathrm{X}$ & & $\mathrm{X}$ \\
\hline 8 & Grouping & & $\mathrm{X}$ & & $\mathrm{X}$ & & $\mathrm{X}$ & & $\mathrm{X}$ \\
\hline 9 & Time & $\mathrm{X}$ & $\mathrm{X}$ & $\mathrm{X}$ & $\mathrm{X}$ & $\mathrm{X}$ & $\mathrm{X}$ & & $X$ \\
\hline \multirow[t]{2}{*}{10} & Place & & & & & & & & \\
\hline & Counts & 5 & 8 & 5 & 8 & 4 & 8 & 2 & 9 \\
\hline
\end{tabular}

Note. ${ }^{*} \mathrm{X}=$ component is present regardless of how clear and detailed it is; $\mathrm{OD}=$ old description; $\mathrm{ND}=$ new description.

\section{What are the effects of the PDA on the middle managers' curriculum development practices?}

To address the behaviour level of Kirkpatrick's model, data were collected an academic semester later through post-intervention interview (2) to explore the participating HoDs' initial efforts to improve their departments' curriculum development practices, especially regarding the (re)writing of the formal curriculum and the application of systematic curriculum development procedures as explained in the developed curriculum policies. Four out of the ten participating HoDs were still in the position of HoD, while some of the others had resigned because of the administrative work pressure and lack of support from the senior management for such a position. Still others quit to further their education through enrolling in graduate programmes. Two out of the four remaining HoDs (Naji and Hassan) took the initiative and started working on their departments' formal curriculum at the course level but could not start applying the curriculum development policies due to implementation challenges. Both HoDs reported having re-described their programme core courses $(50 \%$ and $40 \%$, respectively) through assigning a number of courses to some department teachers who worked on this task individually. However, the HoDs were not satisfied with the quality of the new course descriptions, as some teachers did not use the developed uniform template and some lacked the skill to describe their courses professionally. Hassan explained that the new course descriptions had many weaknesses because teachers lacked experience in phrasing the learning outcomes using measurable verbs. 
All four remaining HoDs were asked about the challenges they encountered in leading their departments' curriculum development work to a better state, based on the concepts learned during the PDA. Analysis of their responses revealed three major implementation challenges. First, all HoDs expressed the need for the senior management's concrete support. The role of the senior management was reported to be neutral and limited to verbal encouragement. The HoDs clearly stated that they needed incentives for teachers to participate in programme/course redesign and financial support so that they could invite experts and organise curriculum development workshops. The following quotations demonstrate the kinds of support the HoDs expected from the senior management:

Naji: The dean, for example, called for me twice after the project [the PDA] was over to check what I am doing, I told him about what we had done in the department, and that we needed to hold curriculum development workshops led by a senior teacher and that such things require resources. He welcomed the idea and thanked me for what I did, and promised to coordinate such workshops but he did not do anything about it.

Tamir: We could not apply any of the policies developed during the project... for example, I couldn't evaluate the courses by the end of the semester. I need a team to work with me; I need a secretary, people to analyze the data to get the results so that I can improve things.

The second challenge concerned the college's organisational and administrative structures. HoDs pointed out that the current administrative structures did not support them in assuming effective curriculum leadership. Examples of administrative barriers included teachers' lack of obligation to be at the college at times other than their teaching times, which made it difficult for HoDs to ask them to come for a meeting to work on curriculum development. Moreover, the college, according to Hassan, lacked curriculum development operational strategies whereby processes, procedures, and responsibilities were outlined. Such a work environment seemed to have crippled the HoDs' initial efforts and kept them distracted from leading programme/course improvements. The following quotations illustrate this second challenge:

Salwa: We could not do that [applying the curriculum policies] because of time; we were busy with the re-describing of courses. First, there was no time. Second, we had problems in the department to solve. There were three courses without teachers to teach.

Tamir: You see that the college does not have a strategy, regulations, or procedures to follow. If resources, staff, policies, and such things are lacking, how can you produce things. If I want to get beans I need to cook beans not eggs! You need inputs to get outputs. We work, here, like doing risk or disaster management. 
The third major challenge pertains to teacher-related issues. The HoDs explained that most teachers were too busy to attend curriculum development meetings, as they had other jobs outside the college or felt demotivated to participate in such undertakings due to the lack of incentives and appreciation from the senior management. Another teacher-related issue concerns the competency of teachers to work on curriculum development, especially the adjunct teachers. The following are some excerpts of what the HoDs had to say:

Hassan: Some teachers have issues with the management, and some teachers do not even come to the college except on their teaching days - both the employed and adjuncts. They do not have to come at other times, which makes meeting them impossible.

Tamir: For me, I think I did [apply systematic procedures in updating/redescribing courses]. But for the other teachers, unfortunately not. Teachers [who collaborated] are new and have not been trained on working systematically.

\section{Discussion and conclusion}

This study explored the design, relevance, and effects of a PDA for a college middle managers that aimed to improve their learning about curriculum development so that they could exercise more effective curriculum leadership in their departments. This single case study did not aim for statistical generalisation but rather endeavoured to contribute to the theoretical understanding of how a specific PDA in a specific context for a specific group of people played out (Borko, 2004; Yin, 2003).

With regard to the study's main question (What are the effects of a PDA on curriculum development for college middle managers practices in a TVET community college?), the findings clearly indicate that the PDA had a substantial impact on the middle managers at the first two levels of Kirkpatrick's model. At the reaction level, there was high appreciation of the PDA and its relevance to the middle managers' work in the curriculum development domain. At the learning level, there was also substantial learning about systematic and relational curriculum development. The findings indicated that the middle managers had increased confidence about leading systematic curriculum development practices in their departments. Not only did the PDA have a positive impact on their learning, but it also changed their beliefs about the concepts of 'curriculum' and 'curriculum development', shifting them towards a broader perspective compared with their previous notions which confined such a process to the updating of the syllabi of individual courses by individual teachers (cf. Darling-Hammond et al., 2009; Wolverton et al., 2005). The reported substantial learning by the middle management can be attributed to the participants' motivation to learn about this skill that they lacked, and to 
the design of the PDA as informed by the conceptual framework and the results of the exploratory study.

However, at the behaviour level, the learning of the remaining middle managers had a minimal transfer to practice due to unsupportive work conditions. The HoDs' inability to function in the curriculum development domain seems to be a consequence of the unstable and confused work environment in which they were operating (Kirkpatrick \& Kirkpatrick, 2006), which also caused a high rate of HoD attrition. Ottevanger, Van de Grint, and Ana'am (2010) reported similar findings in a project conducted in the context of a developing country. They conclude that implementation challenges of curriculum development projects after staff training, especially the lack of organisational support and the management ownership, can greatly hinder the achievement of sustainable outcomes.

This study does have some limitations. The follow-up data came from only four participants due to the high turnover in such academic positions. Further insights could have been gained by interviewing those who left their position as HoD. Greater depth of analysis might have also been obtained by conducting interviews with the senior managers at this college, to get their take on the reported implementation barriers. Despite these limitations, a number of implications derived from this study can be informative for projects addressing a similar problem in a similar context. These implications are discussed next.

\section{Implications and reflections}

For professional development programmes that focus on improving the middle managers' learning about curriculum development to be effective and have sustainable outcomes, major contextual considerations need to be taken into account when designing and implementing these programmes. Based on the study findings and literature from similar contexts, the four design principles (discussed in the conceptual framework) are revisited with the following reflections and recommendations.

\section{Principle 1: attending to managers' learning needs and contextual factors}

An important contextual consideration is the provision of a motivational package, especially monetary incentives, for the middle managers to participate in such programmes and in their follow-up activities. Another important issue is the fast rate of HoDs' turnover, which greatly affects the stability needed for curriculum development projects. HoDs' constant mobility is a common phenomenon in developing contexts, due to the low pay scale and the lack of competitive incentive packages in public TVET institutions; this causes loss of expertise and low morale in academic 
departments (Gervedink Nijhuis et al., 2012; Mellahi, 2000; Smit, Tegegne, \& Van Vliet, 2010). Developers and stakeholders of these programmes need to address the causes of this phenomenon and ensure an encouraging and stable work environment for middle managers. Moreover, non-training solutions should probably be considered along with the training component. These can include the development of internal curriculum policies in a way that addresses the unique context of the TVET institution.

\section{Principle 2: senior management involvement}

Inviting senior managers to the opening and closing workshops and briefing them on progress, as was the case in this study, seem to be inadequate for establishing their ownership and commitment. To improve senior management's ownership and support during implementation, two activities are recommended. First, setting up of a follow-up implementation plan by both the middle and senior management should be an integral part of the design of such programmes, as this can greatly bridge the expectations gap between these two management levels. Second, like the middle managers, senior managers who lack curriculum development expertise should attend a brief version of the programme, so that they develop greater understanding of the organisational and emotional support the middle managers need to lead the various curriculum development tasks associated with the curriculum development domain. Having senior management attend the same training programmes before they are offered to lower level managers helps create a positive work climate and improve post-training practices (Kirkpatrick \& Kirkpatrick, 2006).

\section{Principle 3: time span}

As these programmes and the follow-up activities demand extended time, senior management should provide middle managers with time release, both to attend the training sessions and later on to work on curriculum development tasks. Lack of time due to being busy with teaching and being involved in other work outside the TVET institution is a major barrier that prevents middle managers, in developing contexts, from participating in professional development programmes and/or exercising effective curriculum leadership in practice (Albashiry et al., 2015; Ottevanger et al., 2010).

\section{Principle 4: adoption of multiple delivery strategies}

The use of multiple learning strategies during professional development programmes, for instance, training sessions, exemplary materials, and 
practical tasks can help participants gain basic knowledge about programme/course (re)development. However, for middle managers to develop deeper understanding of systematic and relational curriculum development, they need to work with their department teachers on restructuring their programmes with tailored professional support such as coaching and consultation.

Future research should probably address how such professional development programmes can be integrated into curriculum development projects with the direct supervision and support of senior management. More emphasis needs to be placed on how post-PDA curriculum development practices in TVET institutions can be sustainable in developing countries.

\section{Disclosure statement}

No potential conflict of interest was reported by the authors.

\section{Notes on contributors}

Nabeel M. Albashiry is a lecturer at Sana'a Community College and currently a PhD candidate at the University of Twente. His research interests include curriculum development and teacher professional development in tertiary contexts.

Joke Voogt is Professor of Curriculum, Information, and Communication Technologies at the University of Amsterdam and Windesheim University. Her research interests include teacher involvement and teacher learning through collaborative design to foster sustainable implementation of curriculum innovations in national and international settings, often related to the integration of information and communication technologies.

Jules Pieters is Professor-emeritus of Applied Psychology at the University of Twente. He was involved in research projects on inquiry and collaboration in professional knowledge development of teachers, on co-designing of curriculum materials and learning environments by teachers in teacher development teams, on psychological design, and on knowledge dissemination.

\section{References}

Agrawal, T. (2012). Vocational education and training in India: Challenges, status and labor market outcomes. Journal of Vocational Education \& Training, 64(4), 453-474. doi:10.1080/13636820.2012.727851

Albashiry, N. M., Voogt, J. M., \& Pieters, J. M. (2015). Curriculum design practices of a vocational community college in a developing context: Challenges and needs. Community College Journal of Research and Practice. Advance online publication. doi:10.1080/10668926.2014.942894

Aziz, S., Mullins, M., Balzer, W., Grauer, E., Burnfield, J., Lodato, M., \& CohenPowless, M. (2005). Understanding the training needs of departmental chairs. Studies in Higher Education, 30(5), 571-593. doi:10.1080/03075070500249260

Bakah, M. A. B., Voogt, J. M., \& Pieters, J. M. (2012). Professional development needs of polytechnic lecturers in a curriculum reform scenario. International Journal of Training and Development, 16(1), 67-76. doi:10.1111/j.1468-2419.2011.00389.x

Baqadir, A., Patrick, F., \& Burns, G. (2011). Addressing the skills gap in Saudi Arabia: Does vocational education address the needs of private sector employers?. 
Journal of Vocational Education \& Training, 63(4), 551-561. 10.1080/13636820. 2011.589533

Boateng, C. (2012). Restructuring vocational and technical education in Ghana: The role of leadership development. International Journal of Humanities and Social Science, 2(4), 108-114. Retrieved from http://ijhssnet.com/journals/Vol_2_No_4_Special_Is sue_February_2012/15.pdf

Borko, H. (2004). Professional development and teacher learning: Mapping the terrain. Educational Researcher, 33(8), 3-15. doi:10.3102/0013189×033008003

Bureau of the Conference of Ministers of Education of the African Union. (2007). Strategy to revitalize technical and vocational education and training (TVET) in Africa. Addis Ababa. Retrieved from http://info.worldbank.org/etools/docs/library/243614/ TVET $\% 20$ Strategy $\% 20$ in $\% 20$ Africa.pdf

Chiriboga, C. (2003). Administration 101: Evaluation of a professional development program. New Directions for Community Colleges, 123, 73-81. doi:10.1002/cc.123

Darling-Hammond, L., Meyerson, D., LaPointe, M., \& Orr, M. (2009). Preparing principals for a changing world: Lessons from effective school leadership programs. San Francisco, CA: Jossey-Bass.

Diamond, R. M. (2008). Designing and assessing courses and curricula: A practical guide (3rd ed.). San Francisco, CA: Jossey-Bass.

Finch, C. R., \& Crunkilton, J. R. (1999). Curriculum development in vocational and technical education: Planning, content, and implementation (5th ed.). Boston, MA: Allyn and Bacon

Gervedink Nijhuis, C. J., Voogt, J. M., \& Pieters, J. M. (2012). The cultural complexity of international collaboration: Conditions for sustainable curriculum development in Ghana. International Journal of Intercultural Relations, 36, 647-658. doi:10.1016/j. ijintrel.2012.02.003

Glatthorn, A., Boschee, F., Whitehead, B., \& Boschee, B. (2012). Curriculum leadership (3rd ed.). Los Angeles, CA: Sage.

Gustafson, K. L., \& Branch, R. M. (2002). Survey of instructional development models (4th ed.). Syracuse, NY: ERIC Clearinghouse on Information \& Technology.

Kessels, J. W. M. (1999). A relational approach to curriculum design. In J. Van den Akker, R. Branch, K. Gustafson, N. Nieveen, \& T. Plomp (Eds.), Design and development methodology in education (pp. 59-70). Dordrecht: Kluwer Academic Publishers.

Kessels, J., \& Plomp, T. (1999). A systematic and relational approach to obtaining curriculum consistency in corporate education. Journal of Curriculum Studies, 31(6), 679-709. doi:10.1080/002202799182945

Killian, M., Tendayi, G., \& Augustine, T. (2009). An assessment of partnerships between technical vocational education and training and its stakeholders in the development of Ethiopian SMEs, Economia, Seria Management, 12(2), 39-56. Retrieved from https://ideas.repec.org/a/rom/econmn/v12y2009i2p39-56.html

Kirkpatrick, D. L., \& Kirkpatrick, J. D. (2006). Evaluating training programs: The four levels (3rd ed.). San Francisco, CA: Berrett-Koehler.

Lai, M., \& Lo, L. N. (2008). Perceived workplace competences at three sites on the Chinese mainland. Journal of Vocational Education \& Training, 60(2), 189-204. 10.1080/ 13636820802042461

Lattuca, L., \& Stark, J. (2009). Shaping the college curriculum: Academic plans in context. San Francisco, CA: Jossey-Bass.

Marlow, S., \& Minehira, N. (1996). Principals as curriculum leaders: New perspectives for the 21st century. Honolulu, HI: Pacific Resources for Education and Learning.

Marsh, C. J., \& Willis, G. (1999). Curriculum: Alternative approaches, ongoing issues (2nd ed.). Upper Saddle River, NJ: Prentice Hall. 
Mazani, W. (2013). Strategies for improving polytechnic curriculum effectiveness: A case for Zimbabwe. Unpublished manuscript. Retrieved from http://ahero.uwc.ac.za/ index.php?module=cshe\&action=viewtitle\&id=cshe_921

Mellahi, K. (2000). Human resource development through vocational education in Gulf Cooperation Countries: The case of Saudi Arabia. Journal of Vocational Education and Training, 52(2), 331-347. 10.1080/13636820000200119

Miles, M. B., \& Huberman, A. M. (1994). Qualitative data analysis. Thousand Oaks, CA: Sage.

Nguyen, H. T. (2012). Identifying the training needs of Heads of Department in a newly established university in Vietnam. Journal of Higher Education Policy and Management, 34(3), 309-321. doi:10.1080/1360080X.2012.678730

Ottevanger, W., Van de Grint, L., \& Ana'am, M. (2010). The effectiveness of staff development at universities in Yemen. In M. Cantrell, R. Kool, \& W. Kouwenhoven (Eds.), Access and expansion: Challenges for higher education improvement in developing countries (pp. 91-107). Amsterdam: VU University.

Piskurich, G. M. (2006). Rapid instructional design: Learning ID fast and right. San Francisco, CA: John Wiley \& Sons.

Print, M. (1993). Curriculum development and design. Sydney: Allen and Unwin.

Schell, C. (1992). The value of the case study as a research strategy. Manchester Business School. Retrieved from http://www.finance-mba.com/Case\%20Method.pdf

Shenton, A. K. (2004). Strategies for ensuring trustworthiness in qualitative research projects. Education for Information, 22, 63-75. Retrieved from http://iospress.metapress. com/content/3ccttm2g59cklapx/

Shumaker, J. W. (2013). U.S. Community colleges and a response to the Arab spring. In T. Treat \& L. Hagedorn (Eds.), The community college in a global context: New directions for community colleges (pp. 113-128). San Francisco, CA: Jossey-Bass

Smit, K., Tegegne, T., \& Van Vliet, H. (2010). Tensions between plans and the realities of capacity building and academic cooperation. In M. Cantrell, R. Kool, \& W. Kouwenhoven (Eds.), Access and expansion: Challenges for higher education improvement in developing countries (pp. 147-154). Amsterdam: VU University.

Sorenson, R. D., Goldsmith, L. M., Mendez, Z., \& Maxwell, K. (2011). The principal's guide to curriculum leadership. Thousand Oaks, CA: Corwin Press.

Stark, J. S., Griggs, C. L., \& Rowland-Poplawski, J. (2002). Curriculum leadership roles of chairs in continuously planning departments. Research in Higher Education, 43(3), 329-357. doi:10.1023/A:1014841118080

The European Training Foundation. (2004). Technical education and vocational training in Yemen and its relevance to the labour market. Retrieved from http://www.etf.europa. eu/web.nsf/(RSS)/ C125782 B0048D6F6C125700700289D14? OpenDocument\&LAN $=\mathrm{EN}$

The European Centre for the Development of Vocational Training. (2011). Vocational education and training at higher qualification levels (no. 15). Luxembourg: Publications Office of the European Union. Retrieved from http://www.cedefop.europa.eu/en/pub lications-and-resources/publications/5515

Thomas, D. R. (2006). A general inductive approach for analyzing qualitative evaluation data. American Journal of Evaluation, 27, 237-246. doi:10.1177/1098214005283748

Tyler, R. (1949). Basic principles of curriculum and instruction. Chicago, IL: The University of Chicago Press.

Van den Akker, J. (2003). Curriculum perspectives: An introduction. In J. van den Akker, W. Kuiper, \& U. Hameyer (Eds.), Curriculum landscape and trends (pp. 1-10). Dordrecht: Kluwer Academic Publishers.

Visscher-Voerman, I., Gustafson, K., \& Plomp, T. (1999). Educational design and development: An overview of paradigms. In J. van den Akker, R. M. Branch, K. 
Gustafson, N. Nieveen, \& T. Plomp (Eds.), Design approaches and tools in education and training (pp. 15-29). Dordrecht: Kluwer Academic Publishers.

Wiles, J. (2009). Leading curriculum development. Thousand Oaks, CA: Corwin Press.

Wilson, M., \& Xue, X. (2013). School leader perspectives on leadership learning preparation and continuing professional development in the Chinese province of Fujian: An exploratory study. Educational Management Administration \& Leadership, 41(6), 800-818. doi:10.1177/1741143213494187

Wolverton, M., Ackerman, R., \& Holt, S. (2005). Preparing for leadership: What academic department chairs need to know. Journal of Higher Education Policy and Management, 27(2), 227-238. doi:10.1080/13600800500120126

Yin, R. K. (2003). Case study research, design and methods. Newbury Park, CA: Sage. 